\title{
Atrial fibrillation with flutter episode in patient with mitral stenosis
}

\author{
Deri Arara ${ }^{1}$, Yerizal Karani ${ }^{2}$ \\ 1. Eka Hospital, Pekanbaru; 2. Cardiology and Vascular Medicine, Faculty of Medicine, Universitas \\ Andalas
}

Correspondence: Deri Arara, email: araraderi27@yahoo.com

\begin{abstract}
Mitral stenosis (MS) is a condition which happened because of congenital or acquired event. The most common etiology of MS in Indonesia is Rheumatic Heart Disease (RHD). Chronic inflammation on the mitral valve could lead to stenosis from mild to severe degree. Mitral stenosis could lead to many complications such as pulmonary hypertension and atrial fibrillation (AF). The prevalence of AF in patients with MS is related to the severity of valve obstruction and patient age. AF event in patient with MS could be happen because of Left Atrial (LA) dilatation of the patient. The mechanism that responsible for $A F$ in patient with MS is a complex one. AF even with or without atrial flutter episode could lead a deterioration of patient hemodynamic. In the other way, the patient also predisposes to left atrial thrombus formation and systemic embolic events. Good awareness in diagnosis and management of atrial fibrillation in patient with MS are mandatory to reduce the morbidity and mortality.
\end{abstract}

Keywords: atrial fibrillation; atrial flutter; mitral stenosis; rheumatic heart disease

\begin{abstract}
Abstrak
Mitral stenosis (MS) adalah suatu kondisi yang terjadi karena kejadian bawaan atau didapat. Etiologi MS yang paling umum di Indonesia adalah Penyakit Jantung Rematik (PJR). Peradangan kronis pada katup mitral dapat menyebabkan stenosis dari derajat ringan ke berat. MS dapat menyebabkan banyak komplikasi seperti hipertensi paru dan Atrial Fibrilasi (AF). Prevalensi AF pada pasien dengan MS terkait dengan keparahan obstruksi katup dan usia pasien. Kejadian AF pada pasien dengan MS dapat terjadi karena dilatasi Left Atrial (LA) pasien. Mekanisme yang bertanggung jawab untuk AF pada pasien dengan MS adalah mekanisme yang kompleks. AF bahkan dengan atau tanpa episode atrium flutter dapat menyebabkan penurunan hemodinamika pasien. Dengan cara lain, pasien juga merupakan predisposisi untuk pembentukan trombus atrium kiri dan kejadian embolik sistemik. Kesadaran yang baik dalam diagnosis dan manajemen AF pada pasien dengan MS adalah wajib untuk mengurangi morbiditas dan mortalitas.
\end{abstract}

Kata kunci: atrial fibrillation; atrial flutter; mitral stenosis; penyakit jantung rematik 


\section{INTRODUCTION}

Valvular heart disease accounts for $10 \%$ to $20 \%$ of all cardiac surgical procedures in the United States. The primary causes of valve disease are age-associated calcific valve changes and inherited or congenital conditions. The prevalence of rheumatic valve disease now is very low in the United States and Europe because of primary prevention of rheumatic fever, although rheumatic valve disease remains prevalent in the developing world. ${ }^{1,2}$

The combination of mitral valve disease and atrial inflammation secondary to rheumatic carditis causes left atrial dilation, fibrosis of the atrial wall, and disorganization of the atrial muscle bundles. These changes lead to disparate conduction velocities and inhomogeneous refractory periods. Premature atrial activation, caused by an automatic focus or re-entry, may stimulate the left atrium during the vulnerable period, thereby precipitating Atrial Fibrillation (AF). ${ }^{1,2}$

This case illustration will be discussed about patient who was hospitalized with diagnosis atrial fibrillation with atrial flutter episode and severe mitral stenosis.

\section{CASE}

A-31 years old woman came to the ER of M. Djamil General Hospital with a chief complaint was palpitation since four days before admission. She felt a rapid and irregular heartbeat that happened on rest. She also had history of dizziness without syncope episode. She already had the same complaint 10 years ago but never seek any medical advice.

The patient also had shortness of breath that became worse in the last four days ago. The complaints were becoming worse on activities that made her could not do her daily activities. She admitted that she had history of shortness of breath for 10 years ago but hadn't seek any medical advice too. She routinely slept with 2-3 pillows for five years ago with history of sudden breathlessness on the middle of the night. History of ankle swollen was declined. On her childhood, she had history of recurrent upper respiratory tract infection. When she was on the fourth grade of elementary school, she had history of joint pain that migrating to the other joint and accompanied by high degree of fever. But she never seeks any medical consultation. The patient was referred from private hospital on Ujung Batu by family order without any referring letter.

From physical examination were found that patient on moderate condition with alert of consciousness. Her blood pressure was 116/64 mmHg with heart rate 160-170 bpm (beats per minute), respiratory rate 24 times per minute. Her peripheral arterial saturation was $99 \%$ on four litres per minute nasal cannula. Her jugular vein pressure was $5+3 \quad \mathrm{cmH}_{2} \mathrm{O}$. On chest examination were found that ictus cordis was palpated on 1 finger from left lower midclavicular is border on RIC VI. On auscultation were found an irregularly irregular heartbeat, with a murmur and 
gallop were difficult to defined. On pulmonary examination were found fine bibasilar rales without wheezing.

On electrocardiogram that were recorded in ER of M. Djamil General Hospital were found the atrial fibrillation rhythm with episode of atrial flutter with QRS rate about 160-170 bpm, left axis deviation, without change on ST-T segment as a figure below:

On chest x-ray were found cardiomegaly with cardiothoracic ratio were $68 \%$ with prominent pulmonary segment, flattened cardiac waist with cranialization and infiltrate.

On laboratory examination were found haemoglobin level $13.3 \mathrm{gr} / \mathrm{dL}$, haematocrit $38 \%$, leukocyte $14.720 / \mathrm{mm}^{3}$, thrombocyte $335.000 / \mathrm{mm}^{3}$. Sodium level was 138 $\mathrm{mEq} / \mathrm{dl}$, potassium $4.5 \mathrm{mEq} / \mathrm{dl}$, calcium 9.9 $\mathrm{mEq} / \mathrm{dl}$ and chloride $100 \mathrm{mEq} / \mathrm{dl}$. AST was 39 and ALT $26 \mathrm{mg} / \mathrm{dl}$. Random blood glucose level was $100 \mathrm{mg} / \mathrm{dl}$ with urea 47 and creatinine 0.7 with creatinine clearance $73 \mathrm{ml} / \mathrm{min} / 1.73 \mathrm{~m}^{2}$. Her prothrombin time was 16.7 and APTT 44.2 seconds with INR $1.4 \mathrm{IU}$. On blood gases analysis from vein sample were found that $\mathrm{pH} 7.39, \mathrm{pCO}_{2} 34 \mathrm{mmHg}, \mathrm{pO}_{2} 44 \mathrm{mmHg}$, $\mathrm{HCO}_{3}^{-}$20.6, $\mathrm{BE}-4.4$ and $\mathrm{SpO}_{2}$ 79\%. Her HAS-BLED score was 0.

Patient was diagnosed as AF RVR with atrial flutter episode et causa suspected mitral stenosis (MS) fc III et causa suspected rheumatic heart disease (RHD) with community acquired pneumonia (CAP). Patient had oxygenation with binasal cannula 4 Ipm, IVFD RL 500cc/24 hours, digitalization with digoxin $0.25 \mathrm{mg}$ iv. Four hours after digitalization the heart rate decreased to $110 \mathrm{bpm}$. After that the patient been given with heparin 4000 IU intravenous bolus that maintain with 720 $\mathrm{IU} /$ hour iv. Patient also had warfarin $5 \mathrm{mg}$ od (once daily), digoxin $0.25 \mathrm{mg}$ od, furosemide $20 \mathrm{mg}$ bid (iv) and RL $500 \mathrm{cc} / 24$ hour. Patient also consulted to pulmonology department and was assessed as CAP and had ceftriaxone $2 \mathrm{~g}$ od (iv), n-acetylcysteine $300 \mathrm{mg}$ bid (iv) and nebulization with salbutamol every six hour. Patient was planned to be performed echocardiography examination on the next day, and check PT, APTT, and INR because she was on heparinization.

On the second day of hospitalization, the palpitation and shortness of breath were decreased. Her BP was 98/62 mmHg, HR was 96 bpm irregularly irregular, with RR 20 time per minute. On physical examination were found mid-diastolic murmur grade III/IV and opening snap on apex. Her fluid balance was $-150 \mathrm{cc} / 18$ hours with urine output was 0.95 $\mathrm{cc} / \mathrm{kgBW} / \mathrm{h}$. The therapy continued with UFH 720 IU/h (APTT 79.5 s). Patient were moved to cardiology Ward.

On the third day patient was hemodynamically stable and had echocardiography with the result moderate-severe MS with MVA $0.8 \mathrm{~cm} 2$ (planimetry) and $1.1 \mathrm{~cm} 2$ (VTI), moderate mitral regurgitation (MR) ec RHD (Wilkins score 9), mild aortic regurgitation (AR) ec $\mathrm{RHD}$, moderate tricuspid regurgitation (TR) 
with TVG $50 \mathrm{mmHg}$ and high probability pulmonary hypertension (PH) with MPAP $40 \mathrm{mmHg}$, good LV function (EF 62\%), global normo kinetic, good RV contractility (TAPSE $1.8 \mathrm{~cm}$ ), with SEC and thrombus in left atrium (LA) with minimal pericardial effusion on posterior wall. On this day patient was started to get bisoprolol 1.25 $\mathrm{mg}$ od and warfarin were reduced to $2 \mathrm{mg}$ od. On the fourth- and fifth-day patient was in a stable condition. She still had atrial fibrillation rhythm but in a normo ventricular response.

On the sixth day patient was discharge with therapy bisoprolol $1 \times 2.5 \mathrm{mg}$ od, furosemide $40 \mathrm{mg}$ od, warfarin $2 \mathrm{mg}$ od. Patient were advised to control to outpatient cardiology clinic in M. Djamil General Hospital to be prepared to have mitral valve replacement surgery.

\section{DISCUSSIONS}

Were reported a-31 years old woman with diagnosis $A F \quad R V R$ with atrial flutter episode, MS NYHA fc III and CAP. Based on anamnesis, physical examination, electrocardiogram, and other modalities patient was diagnosed as atrial fibrillation because of mitral stenosis. Based on the literature, dyspnoea is the most common presenting symptoms of MS. Symptoms may be caused by a reduced ability to increase cardiac output normally with exercise or elevated pulmonary venous pressures and reduced pulmonary compliance. $^{1}$

Dyspnoea may be accompanied by cough and wheezing. Vital capacity is reduced, presumably because of the presence of engorged pulmonary vessels and interstitial oedema. Tachycardia that been resulted from exercise, pregnancy, hyperthyroidism, anaemia, infection, or AF. All these will make increase the rate of blood flow across the mitral orifice, resulting in further elevation of the left atrial pressure, and decrease the diastolic filling time, resulting in a reduction in forward cardiac output. ${ }^{1,2}$

The most common findings on physical examination in patients with MS are an irregular pulse caused by AF and signs of left- and right-heart failure. Patients with severe chronic MS, a low cardiac output, and systemic vasoconstriction may exhibit the so-called mitral facies, characterized by pinkish-purple patches on the cheeks. ${ }^{1}$ In this patient had found irregularly irregular rhythm that cause by atrial fibrillation.

When the heart rate was reduced to normal limit, on physical examination of the patient were found mid-diastolic murmur grade III/IV and opening snap. The diastolic, low-pitched, rumbling murmur of MS is best heard at the apex, with the bell of the stethoscope and with the patient in the left lateral recumbent position. Opening snap is a sharp, high-pitched sound, and its timing does not vary significantly with respiration. In mitral stenosis the OS is heard best between the apex and the left sternal border, just after the aortic closure sound (A2), when the left ventricular pressure falls below that of the left atrium. . $6,8^{-}$ 
The ECG is relatively insensitive for detecting mild MS, but it does show characteristic changes in moderate or severe obstruction. Left atrial enlargement (LAE) is a principal electrocardiographic feature of MS and is found in $90 \%$ of patients with significant MS and sinus rhythm. The electrocardiographic signs of LAE correlate more closely with left atrial volume often regress after successful valvotomy. $\mathrm{AF}$ is common with longstanding MS, as noted. ${ }^{1,2}$ From the chest $\mathrm{x}$-ray, patients with hemodynamically significant MS almost invariably have evidence of left atrial enlargement on the lateral and left anterior oblique views. ${ }^{1}$

Echocardiography is the most accurate approach to the diagnosis and evaluation of MS. It is recommended for all patients with MS at initial presentation, for reevaluation of changing symptoms or signs, and at regular intervals (depending on disease severity) for monitoring disease progression. Imaging shows the characteristic anatomy with leaflet thickening and restriction of opening caused by symmetric fusion of the commissures, resulting in "doming" of the leaflets in diastole. As disease becomes more severe, thickening extends from the leaflet tips toward the base, with further restriction of motion and less curvature of the leaflet in diastole. ${ }^{1,9}$

Mitral valve area is measured by direct planimetry from two-dimensional shortaxis images and calculated by the Doppler pressure half-time and PISA (proximal isovelocity surface area) methods. Evaluation of the morphology of the valve is helpful for predicting the hemodynamic results and outcome of percutaneous BMV. A mitral valve with a score less than 8 to 9 with no more than moderate mitral regurgitation is deemed the best candidate for PBMV. ${ }^{10,11}$ From the echo result this patient had MVA $0.8 \mathrm{~cm}^{2}$ (planimetry) and $1.1 \mathrm{~cm}^{2}$ (VTI) and her Wilkins score was 9.

$\mathrm{AF}$ is the most common complication of MS. The prevalence of AF in patients with MS is related to the severity of valve obstruction and patient age. Even when MS is severe, the prevalence of $A F$ is related to age. AF may precipitate or worsen symptoms caused by loss of the atrial contribution to filling and to a short diastolic filling period when the ventricular rate is not well controlled. In addition, AF predisposes affected patients to left atrial thrombus formation and systemic embolic events. $^{1,2}$

The mechanisms responsible for $A F$ are complex. Triggering events may differ from maintenance mechanisms. In addition, the clinical phenotypes of paroxysmal, persistent, and longstanding persistent AF have different electrophysiologic characteristics because of remodeling and different clinical modulators that affect the substrate, such as heart failure, atrial stretch and ischemia, sympathovagal influences, inflammation, and fibrosis. ${ }^{12,13}$

Atrial flutter occurs commonly in association with $A F$, and 3 of every 4 patients with atrial flutter will, at some time, manifest clinical AF. The term atrial 
flutter is generally used to describe atrial arrhythmias with large reentrant circuits. The surface ECG is characterized by regular repetitive flutter waves with an undulating baseline. Atrial flutter associated with chronic obstructive pulmonary disease, mitral or tricuspid valve disease, thyrotoxicosis, and postsurgical repair of certain congenital cardiac lesions, as well as enlargement of the atria for any reason, especially the right atrium. ${ }^{3,14}$

Pulmonary hypertension in patients with MS results from the following: (1) passive backward transmission of the elevated left atrial pressure; (2) pulmonary arteriolar constriction, which presumably is triggered by left atrial and pulmonary venous hypertension (reactive pulmonary hypertension); and (3) organic obliterative changes in the pulmonary vascular bed, which may be considered to be a complication of longstanding and severe MS. In time, severe pulmonary hypertension results in right-sided heart failure, with dilation of the right ventricle and its annulus, secondary tricuspid regurgitation (TR), and sometimes pulmonic regurgitation. ${ }^{1,2}$

In patients with severe MS, with persistent symptoms after intervention or when intervention is not possible, medical therapy with oral diuretics and the restriction of sodium intake may improve symptoms. Digitalis glycosides do not alter the hemodynamic and usually do not benefit patients with MS and sinus rhythm, but these drugs are of value in slowing the ventricular rate in patients with $\mathrm{AF}$ and in treating patients with right-sided heart failure. Hemoptysis is managed by measures designed to reduce pulmonary venous pressure, including sedation, assumption of the upright position, and aggressive diuresis. Beta-adrenergic blocking agents and rate-slowing calcium antagonists may increase exercise capacity by reducing heart rate in patients with sinus rhythm, especially in patients with AF. ${ }^{1,2}$

Management of AF for patients with MS is similar to management for AF of any cause. However, it typically is more difficult to restore and maintain sinus rhythm because of pressure overload of the left atrium in conjunction with effects of the rheumatic process on atrial tissue and the conducting system. Immediate treatment of AF includes administration of intravenous heparin followed by oral warfarin. The ventricular rate should be slowed, initially with an intravenous beta blocker or nondihydropyridine calcium channel antagonist, followed by long-term rate control with oral doses of these agents. When these medications are ineffective or when additional rate control is necessary, digoxin or amiodarone may be considered. If cardioversion is planned in a patient who has had AF for more than 24 hours before the procedure, anticoagulation with warfarin for more than 3 weeks is indicated. Alternatively, if TEE results show no atrial thrombus, immediate cardioversion can be carried out provided the patient is effectively anticoagulated with intravenous heparin before and during 
the procedure, and with warfarin chronically thereafter. ${ }^{1,2,4}$

In patients who cannot be converted or maintained in sinus rhythm, digitalis should be used to maintain the ventricular rate at rest at approximately 60 beats/min. If this is not possible, small doses of a betaadrenergic blocking agent, such as atenolol (25 mg daily) or metoprolol (50 to $100 \mathrm{mg}$ daily), may be added. Beta blockers are particularly helpful in preventing rapid ventricular responses that develop during exertion. Multiple repeat cardioversions are not indicated if the patient fails to sustain sinus rhythm while on adequate doses of an antiarrhythmic. ${ }^{4}$

The optimal heart rate target in AF patients is unclear. The RACE (Rate Control Efficacy in Permanent Atrial Fibrillation) II study randomized 614 patients with permanent AF to either a target heart rate $80 \mathrm{bpm}$. at rest and $110 \mathrm{bpm}$. during moderate exercise, or to a lenient heart rate target of $110 \mathrm{bpm}^{4}$

Anticoagulant therapy is indicated for prevention of systemic embolism in patients with MS and AF (persistent or paroxysmal), any previous embolic events (even if in sinus rhythm) and documented left atrial thrombus. ${ }^{5}$ The target INR for patient who undertreatment with warfarin should be 2.0 to 3.0. This range of INRs provides the best balance between stroke prevention and haemorrhagic complications. Maintaining the INR at a level of 2.0 or higher is important because even a relatively small decrease in the INR from 2.0 to 1.7 more than doubles the risk for stroke. ${ }^{4,15}$

The pulmonary venous hypertension should always be targeted at the underlying cause. In many patients, a reduction in leftsided filling pressure will result in a reduction in pulmonary artery pressure. Emphasis should be placed on blood pressure control, volume management, and sodium restriction. No PAH-specific therapy is currently approved for the treatment of pulmonary venous hypertension. In the setting of left ventricular systolic dysfunction, both proteinoids and endothelin receptor antagonists have been studied and have failed to demonstrate a treatment benefit and may even be harmful. ${ }^{1,5}$

Most patients with favourable valve anatomy currently undergo PMC; however, open commissurotomy may be preferred by experienced surgeons in young patients with mild-to-moderate MR. In asymptomatic patients with MS, surgery is limited to those rare patients at high risk of complications and with contraindications to PMC. ${ }^{1,5}$ In this case, the patient should have mitral valve surgery because she had thrombus on her left atrium which is one of the contraindications to PMC.

\section{CONCLUSIONS}

Atrial fibrillation with atrial flutter episode in this patient might be happened because remodelling of her cardiac structure. The remodelling is the result from high pressure on left atrium because mitral stenosis. The patient had intravenous 
digoxin administration for her atrial fibrillation then bisoprolol when her heart failure was treated. She also had anticoagulant for her AF and for thrombus on left atrium. Pulmonary hypertension that happened to her is a complication from mitral stenosis itself. So, we should treat the main cause from this disease. She should have mitral valve surgery as a definitive treatment, because she had a contraindication to PMC.

\section{REFERENCES}

1. Otto CM, Bonow R. 2015. Valvular Heart Disease. In: Mann D, Zipes D, Libby P, Bonow R, eds. Braunwald's Heart Disease: A Textbook of Cardiovascular Medicine. $10^{\text {th }}$ Edition. Philadelphia: Elsevier; 2015. P.1446-1480.

2. Prystowsky EN, Padanilam BJ, Waldo AL. Atrial Fibrillation, Atrial Flutter, and Atrial Tachycardia. In: Fuster V, Walsh RA, Harrington RA, eds. Hurst's The Heart. New York: The McGraw-Hill Companies; 2011. P.963-987.

3. Rodriguez L, Gillinov AM. Mitral Valve Disease. In: Topol EJ, Califf RM, eds. Textbook of Cardiovascular Medicine. $3^{\text {rd }}$ Edition. Ohio: Lippincott Williams \& Wilkins; 2007. P.346-363.

4. Kirchhof P, Benussi S, Kotecha D, Ahlsson A, Atar D, Casadei B, et al. 2016 ESC Guidelines for The Management of Atrial Fibrillation Developed in Collaboration with EACTS. European Heart Journal. 2016; 37(38):2893-2962. doi: 10.1093/eurhearti/ehw210.

5. Joint Task Force on the Management of Varvular Heart Disease of the European Society of Cardiology (ESC), European Association for Cardio-Thoracic Surgery (EACTS), Vahanian A, Alfieri $\mathrm{O}$, Andreotti $\mathrm{F}$, Antunes MJ, et al. Guidelines on the management of valvular heart disease (version 2012). European Heart Journal. 2012; 33(19):2451-2496. doi: 10.1093/eurhearti/ehs109.

6. Constant J. The Opening Snap. In: Constant J, ed. Essentials of Bedside Cardiology. $2^{\text {nd }}$ Edition. New Jersey: Humana Press; 2003. P.155-165.

7. Jung H, Lilly LS. 2011. The Cardiac Cycle: Mechanisms of Heart Sounds and Murmur. In: Lilly LS, ed. Pathophysiology of Heart Disease. Massachusetts: Lippincott Williams \& Wilkins; 2011. P.3536.

8. Ranganathan N, Sivaciyan V, Saksena FB. Heart Sounds. In: Ranganathan N, Sivaciyan V, Saksena FB, eds. The Art and Science of Cardiac Physical Examination. $2^{\text {nd }}$ Edition. New Delhi: The Health Sciences Publisher; 2016; P.220-233.

9. Morady F, Zipes D. Atrial Fibrillation: Clinical Features, Mechanisms, and Management. In: Mann DL, Zipes DP, Libby P, Bonow RO, eds. Braunwald's Heart Disease: A Textbook of Cardiovascular Medicine. $10^{\text {th }}$ Edition. Philadelphia: Saunders; 2015. P.798-820.

10. Hu R, Stevenson WG, Lilly LS. Clinical Aspects of Cardiac Arrhythmias. In: Lilly LS, ed. Pathophysiology of Heart Diseases. Massachusetts: Lippincott Williams \& Wilkins; 2011. P.284301.

11. Omran AS, Arifi AA, Mohamed AA. 2011. Echocardiography in Mitral Stenosis. Journal of the Saudi Heart Association. 2011; 23(1): 51-58. doi: 10.1016/i.jsha.2010.07.007. 
12. Nobuyoshi M, Arita T, Shirai S, Hamasaki N, Yokoi H, Iwabuchi M, et al. Percutaneous Ballon Mitral Valvuloplasty. Circulation. 2008; 119:e211-219. doi:

10.1161/CIRCULATIONAHA.108.792952.

13. Nunes MC, Tan TC, Elmariah S, do Lago R, Margey R, Cruz-Gonzalez I, et al. Impact of Incorporating Commisural Morphology and Leaflet Displacement to the Prediction of Outcome for Patients Undergoing Percutaneous Mitral Valvuloplasty. Circulation. 2014; 129(8):886-895. doi: 10.1161/CIRCULATIONAHA.113.001252.

14. Andrade J, Khairy P, Dobrev D, Nattel S. The Clinical Profile and Pathophysiology of Atrial Fibrillation: Relationships Among Clinical Features, Epidemiology, and Mechanisms. Circ Res. 2014; 114(9):1453-1468. doi: 10.1161/CIRCRESAHA.114.303211.

15. Fox KA, White HD, Gersh BJ, Opie LH. Antithrombotic Agents: Platelet Inhibitors, Acute Anticoagulants, Fibrinolytics, and Chronic Anticoagulants. In: Opie LH, Gersh BJ, eds. Drugs for The Heart. $8^{\text {th }}$ Edition. Philadelphia: Saunders; 2013. P.332-367. 